\title{
PENYELESAIAN SENGKETA PERBANKAN MELALUI LEMBAGA MEDIASI PERBANKAN
}

\author{
Muhamad Kholid \\ Dosen Fakultas Syariah dan Hukum \\ Universitas Islam Negeri Sunan Gunung Djati Bandung
}

\begin{abstract}
Abstrak
Lembaga mediasi perbankan terbilang baru karena sebelum aturan ini keluar fungsi mediasi untuk penyelesaian sengketa perbankan dilaksanakan oleh Bank Indonesia (BI).Mediasi di bidang perbankan dilakukan oleh lembaga Mediasi perbankan independen yang dibentuk asosiasi perbankan. Sebelumnya telah dibentuk lembaga mediasi perbankan independen melalui PBI No: 8/5/PBI/2006. Namun lembaga ini perlu untuk melakukan evaluasi terhadap efektifitas penyelesaian sengketa perbankan. Tulisan ini akan memberikan deskripsi tentang peran lembaga mediasi dalam membantu menyelesaikan sengketa perbankandengan cara sederhana, murah, dan cepat.
\end{abstract}

\section{Kata Kunci:}

Mediasi,independen,penyelesaian sengketa,asosiasi perbankan

\section{A. Pendahuluan}

\section{Latar belakang}

Perbankan merupakan salah satu sarana dalam pembangunan di bidang ekonomi suatu negara. Peranannya sangat signifikan, karena perbankan berfungsi secara umum sebagai lembaga penghimpun dana dari masyarakat (funding) dan menyalurkannya ke masyarakat (lending) dalam bentuk kredit atau pembiayaan yang sering dikenal dengan fungsi lembaga intermediasi (intermediation institution).

Fungsi-fungsi perbankan tersebut diterapkan dalam kegiatan usahanya (termasuk proses dan cara) dengan tujuan menunjang pelaksanaan pembangunan nasional dalam rangka meningkatkan pemerataan, pertumbuhan ekonomi, dan stabilitas nasional kearah peningkatan taraf hidup (kesejahteraan) rakyat banyaksebagaimana diamanatkan dalam Pasal 1 ayat (2)Undang-undang Nomor 10 
128 | Adliya, Vol. 8 No. 1, Edisi: Januari-Juni 2014

Tahun 1998 tentang Perubahan Atas Undang-undang Nomor 7 Tahun 1992 tentang Perbankan Jo Pasal 4 Undang-undang Nomor 7 Tahun 1992 tentang Perbankan.

Perkembangan perbankan di Indonesia mengiringi sejarah pembentukan dan pertumbuhan negara ini. Bahkan sebelum negara ini terbentuk, lembaga perbankan di Indonesia sudah ada terlebih dahulu karena perbankan merupakan seperangkat sistem pembayaran yang di bawa dan digunakan oleh VOC (Vereenigde Oost-indische Compagnie) dalam ekspedisi perdaganganya ke wilayah-wilayah yang disinggahinya. Perusahaan yang digunakan VOC dalam menjalankan fungsi bank adalah de Nederlandsche Handel Maatschappij (NHM), sedangkan perusahaan untuk menjalankan usaha bank adalah N.V De Javansche Bankyang didirikan pada abad ke-19 dengan modal 1 juta golden.

Setelah itu baru perkembangan perbankan Indonesia lebih berkembang, yaitu dengan berdirinya N.V. Escompto Bank pada tahun 1857 sebagai bank swasta yang bergerak di bidang usaha bank umum di Hindia Belanda dan berdirinya Bank Priyayi (De Poerwokertosche Hulpen Spaarbank de Indandsche Hoofden) pada tahun 1895 sebagai bank yang khusus melayani penduduk golongan pribumi oleh Patih Raden Wiriaatmadja yang modalnya berasal dari kas mesjid. Pada tahun 1898 pemerintah Hindia Belanda bekerja sama dengan Jawatan Pos untuk mendirikan De Postparbank berdasarkan Stbl. 1897 No.296.Perkembangan Dunia perbankan jaman Hindia Belanda tidak hanya dipelopori oleh berdirinya bank dengan modal nasional tetapi juga berdiri bank bermodal asing seperti Jepang, Belanda dan Cina seperti The Matsui Bank, de Algemeene Volkscrediet Bank, The Bank of China.

Perkembangan perbankan pada awal kemerdekaan di awali dengan dinasionalisasinya De Javancshe Bankmenjadi Bank Indonesia melalui Undang-undang Nomor 11 Tahun 1953.Selanjutnya pemerintah mendirikan bank baru sebagai alat perjuangan bank sentral, yaitu BNI 1946 berdasarkan Perpu No. 2 tahun 1946 dan berdiri beberapa bank nasional swasta diantaranya Bank Surakarta MAI di Solo, Bank Dagang Nasional di Medan, dan lain-lain. Selain De Javancshe Bankyang dinasionalisasi menjadi Bank Indonesia terdapat bank-bank lain yaitude Algemeene Volkscrediet Bank(AVB) menjadi 
Bank Perkreditan Rakyat (BRI), De Postpaarbank menjadi Bank Tabungan Negara (BTN) dan NV Escompto Bank menjadi Bank Dagang Negara (BDN).

Di Indonesia terdapat perkembangan yang sangat penting (signifikan) dari sisi perkembangan peraturan yang mengatur kegiatan usaha perbankan yaitu lahirnya Undang-undang Nomor 7 Tahun 1992 tentang Perbankan yang mulai menggunakan prinsip bagi hasil sebagaimana diatur dalam Pasal 1 ayat (12) tentang definisi kredit. Undang-undang ini menjadi gerbang mulai di gunakannya prinsipprinsip syariah dalam kegiatan usaha perbankan di Indonesia, hanya saja masih menggunakan kalimat yang belum jelas (inplisit) yaitu menggunakan kalimat "imbalan atau pembagian hasil keuntungan".

Baru setelah adanya perubahan atas Undang-undang Nomor 7 Tahun 1992 yaitu keluarnya Undang-undang Nomor 10 Tahun 1998 tentang Perbankan yang lebih jelas (eksplisit) menyebutkan pembiayaan berdasarkan prinsip-prinsip syariah sebagaimana diatur dalam Pasal 1 ayat (12) dan (13) tentang definisi Pembiayaan Berdasarkan Prinsip Syariah dan Prinsip Syariah. Dengan demikian di Indonesia dalam dunia perbankan menggunakan dua sistem perbankan (dual banking system) yaitu bank konvensional yang menggunakan bunga dalam kegiatan usahanya dan bank syariah yang menggunakan prinsip-prinsip syariah dengan sistem bagi hasil (lose and profit sharing system).

Berdasarkan data yang dirilis Direktori Perbankan Indonesia tahun 2013 bahwa jumlah perbankan konvensional di Indonesia adalah4 Bank Pesero, 35 Bank Swasta Nasional Devisa, 30 Bank Swasta Nasional Non Devisa, 26 Bank Pembangunan Daerah, 15 Bank Campuran dan 10 Bank Asing. Sedangkan jumlah dan 31 Layanan Syariah (Office Channeling). ${ }^{1}$

Hal penting yang harus diantisipasi dan diperhatikan dalam perkembangan Bank di Indonesia adalah masalah penyelesaian sengketa. Pasal 16 ayat (1) dan (2) Undang-undang Nomor 4 Tahun 2004 tentang Kekuasaan Kehakiman berbunyi sebagai berikut:

"Pengadilan tidak boleh menolak untuk memeriksa, mengadili, dan memutus suatu perkara yang diajukan dengan dalih bahwa

${ }^{1}$ www.bi.go.id. 
hukum tidak ada atau kurang jelas, melainkan wajib untuk memeriksa dan mengadilinya". "Ketentuan sebagaimana dimaksud pada ayat (1) tidak menutup usaha penyelesaian perkara perdata secara perdamaian."

Berdasarkan aturan di atas, lembaga-lembaga yang berwenang untuk memeriksa, mengadili, dan memutus sengketa-sengketa perbankan dapat dilakukan dengan dua cara, yaitu melalui lembaga litigasi yakni Pengadilan Negeri dan Pengadilan Agamaatau melalui lembaga non litigasi yakni lembaga Unit Pengaduan Internal Bank (Peraturan Bank Indonesia Nomor: 7/7/PBI/2005 tentang Penyelesaian Pengaduan Nasabah), Lembaga Mediasi Perbankan (Peraturan Bank Indonesia Nomor: 8/5/PBI/2006 tentang Mediasi Perbankan), Musyawarah/Konsultasi, Mediasi, dan Arbitrase (Undang-undang Nomor 30 Tahun 1999 tentang Arbitrase dan Alternatif Penyelesaian Sengketa).

Pada umumnya kalangan dunia usaha lebih menyukai penyelesaian sengketanya melalui lembaga luar pengadilan seperti melalui lembaga mediasi atau lembaga arbitrase. Hal ini dikarenakan penyelesaian sengketa melalui lembaga luar pengadilan memiliki keunggulan yaitu kerahasiaan para pihak yang bersengketa di jamin kerahasiaannya, putusan yang dihasilkan dalam Akta Kesepakatan atau Putusan Arbitrase (Badan Arbitrase Nasional Indonesia atau Badan Arbitrase Syariah Nasional) memiliki kekuatan mengikat kepada para pihak dan tidak ada upaya hukum (final and binding) serta memiliki kekuatan eksekutorial, para pihak yang bersengketa dapat menentukan para arbiter, hukum yang akan digunakan (choice of law), proses, tempat penyelenggaraan dan kelenturan prosedural.

Apabila para pihak sepakat untuk menyelesaikan sengketa perkaranya melalui lembaga mediasi independen maka terlebih dahulu harus melewati tahapan penyelesaian melalui pengaduan nasabah yang dilakukan di lembaga Unit Pengaduan Internal Bank.Aturan ini diatur dalam Pasal 1 ayat 4 PBI No: 8/5/PBI/2006 tentang pengertian sengketa, yang berbunyi sebagai berikut:

"Sengketa adalah permasalahan yang diajukan oleh Nasabah atau Perwakilan Nasabah kepada penyelenggara mediasi perbankan, setelah melalui proses penyelesaian pengaduan oleh 
Bank sebagaimana diatur dalam PBI tentang Penyelesaian Pengaduan Nasabah."

Batas waktu penyelesaian pengaduan nasabah di unit internal bank paling lambat selama 40 (empat puluh) hari sejak pendaftaran pengaduan nasabah diterima. Apabila nasabah tidak merasa puas dengan hasil putusan Unit Pengaduan Internal Bank maka nasabah dapat mengajukan kembali sengketanya ke lembaga mediasi independen.

Menurut Pasal 1 ayat 5 PBI No: 8/5/PBI/2006 tentang Mediasi Perbankan bahwa pengertian mediasi adalah proses penyelesaian sengketa yang melibatkan mediator untuk membantu para pihak yang bersengketa guna mencapai penyelesaian dalam bentuk kesepakatan sukarela terhadap sebagian ataupun seluruh permasalahan yang disengketakan.Proses Mediasi dapat dilaksanakan apabila para pihak yakni Nasabah atau Perwakilan Nasabah dengan Bank menandatangani perjanjian Mediasi (agreement to mediate) yang memuat kesepakatan memilih Mediasi sebagai tempat penyelesaian sengketanya (choice of forum) dan persetujuan untuk patuh dan tunduk pada aturan Mediasi yang ditetapkan oleh Bank Indonesia.

Pertimbangan hukum keluarnya PBI No: 8/5/PBI/2006 tentang Mediasi Perbankan adalah sebagai berikut:

a. Bahwa penyelesaian pengaduan nasabah oleh bank tidak selalu dapat memuaskan nasabah dan berpotensi menimbulkan sengketa di bidang perbankan antara nasabah dengan bank.

b. Bahwa penyelesaian sengketa di bidang perbankan yang berlarut-larut dapat merugikan nasabah dan meningkatkan risiko reputasi bagi bank.

c. Bahwa penyelesaian sengketa di bidang perbankan antara nasabah dengan bank dapat dilakukan secara sederhana, murah, dan cepat melalui cara mediasi.

Berdasarkan pertimbangan-pertimbangan di atasmaka dipandang perlu untuk mengatur mediasi perbankan dalam suatu Peraturan Bank Indonesia. Lembaga mediasi perbankan terbilang baru karena sebelum aturan ini keluar fungsi mediasi untuk penyelesaian sengketa perbankan dilaksanakan oleh Bank Indonesia (BI). 
Mediasi di bidang perbankan dilakukan oleh lembaga Mediasi perbankanindependen yang dibentuk asosiasi perbankan yang dalam pelaksanaan tugasnya, lembaga Mediasi perbankan independen melakukan koordinasi dengan Bank Indonesia. Pembentukan lembaga Mediasi perbankan independen dilaksanakan selambat-lambatnya 31 Desember 2007.Setelah 6 tahun lebih sejak keluarnya aturan tentang batas waktu pembentukan lembaga mediasi perbankan independen melalui PBI No: 8/5/PBI/2006 tentang Mediasi Perbankan, dianggap perlu untuk melakukan evaluasi terhadap efektifitas penyelesaian sengketa perbankan melalui lembaga mediasi ini.

\section{Perumusan Masalah}

Berdasarkan uraian latar belakang di atas, Peneliti merumuskan masalah penelitian yaitu bagaimana pelaksanaan penyelesaian sengketa perbankan melalui lembaga mediasi perbankan?

\section{B. Metode Penelitian}

Metode pendekatan yang dipergunakan dalam penelitian ini adalah yuridis-normatif dengan spesifikasi deskriftif-analitis yaitu penelitian hukum yang dilakukan dengan cara meneliti dan mengkaji bahan-bahan pustaka (bahan sekunder) yang mencakup bahan hukum primer, sekunder, dan tersier ${ }^{2}$ yang terkait pelaksanaan penyelesaian sengketa perbankan melalui Lembaga Mediasi Perbankan Independen dan menggambarkan secara sistematis, faktual, dan akurat segala fakta dan permasalahan yang diteliti dikaitkan dengan teori hukum dan praktik pelaksanaan hukum positif yang menyangkut permasalahan dalam perumusan masalah. ${ }^{3}$

\section{Pembahasan}

\section{Pelaksanaan Penyelesaian Sengketa Perbankan Melalui Lembaga Mediasi Perbankan.}

Kegiatan usaha bank selaku badan usaha adalah menghimpun dana dari masyarakat dalam bentuk simpanan dan menyalurkannya

2 Soerjono Soekanto, Pengantar Penelitian Hukum, Penelitian UI-Press, Jakarta, 1986, hlm. 52

${ }^{3} \mathrm{Ibid}, \mathrm{hlm} .10$. 
kepada masyarakat dalam bentuk kredit dan/atau bentuk-bentuk lainnya dalam rangka meningkatkan taraf hidup rakyat banyak. (Pasal 1 ayat (1) UU No.7 Tahun 1992 dan Pasal 1 ayat (2) UU No.10 Tahun 1998). Kegiatan menghimpun dana (funding) dilakukan melalui simpanan/investasi diantaranya adalah Simpanan Giro (demand deposit), Simpanan Tabungan (saving deposit), dan Simpanan Deposito (time deposit). Sedangkan kegiatan menyalurkan dana (lending) dilakukan melalui Kredit dan Pembiayaan, diantaranya melalui Kredit/Pembiayaan Investasi, Kredit/Pembiayaan Modal Kerja, dan Kredit/Pembiayaan Perdagangan. Jasa-jasa yang dilakukan oleh bank diantaranya adalah Transfer, Clearing, Inkaso, Letter of Credit, Safe Deposite Box, Bank Garansi, dan Travellers Cheque.

Banyaknya jumlah (kuantitas) kegiatan perbankan yang dilakukan oleh bank ditambah pula dengan banyaknya jumlah lembaga perbankan yang ada di Indonesia, baik Bank Umum/Bank Umum Syariah maupun Bank Perkreditan Rakyat/Bank Perkreditan Rakyat Syariah menyebabkan peran lambaga perbankan sangat penting dalam roda perekonomian nasional, sehingga sangat penting untuk selalu diadakan pembinaan dan pengawasan secara rutin.

Banyaknya kegiatan usaha yang dilakukan bank, tidak mungkin bisa menghindari dari adanya sengketa (conflict) antara para pihak (nasabah/wakilnya dengan bank). Apabila sengketa-sengekta yang ada tidak segera diselesaikan secara cepat dan efektif maka akan menjadi halangan tersendiri bagi keberlanjutan operasional bank, terlebih apabila sudah memudar bahkan hilang kepercayaan masyarakat (distrust) terhadap bank maka akan mengancam keberadaan (eksistensi) bank itu sendiri bahkan lebih besar lagi akan berdampak sistemik pada kepercayaan terhadap bank-bank yang lainnya, secara skala besar (makro) akan mengancam kestabilan perekonomian nasional.

Penyelesaian sengketa melalui cara-cara konvensional yaitu melalui lembaga peradilan (litigation) yang memiliki karakteristik sangat prosuderal, terdapat upaya hukum (verzet, banding, kasasi, derden verzet, dan peninjauan kembali), persidangan terbuka untuk umum, dan putusan harus diucapkan dalam sidang terbuka untuk umum maka akan sangat tidak efektif dalam penyelesaian sengketa perbankan yang membutuhkan penyelesaian secara cepat dan efektif. 
Penyelesaian sengketa di bidang perbankan yang berlarut-larut dapat merugikan nasabah dan meningkatkan risiko reputasi bagi bank. Dengan demikian penyelesaian sengketa di bidang perbankan antara nasabah dengan bank dapat dilakukan secara sederhana, murah, dan cepat.

Poin penyelesaian sengketa di bidang perbankan antara nasabah dengan bank menjadi salah satu hal yang difokuskan dalam mengelola perbankan di Indonesia yaitu dengan memasukan dalam 6 (enam) pilar Arsitek Perbankan Indonesia yaitu:

1. Struktur perbankan yang sehat

2. Sistem pengaturan yang efektif

3. Sistem pengawasan yang independen dan efektif

4. Industri perbankan yang kuat

5. Infrastruktur pendukung yang mencukupi

6. Perlindungan konsumen.

Upaya perlindungan konsumen dituangkan dalam 4 (empat) aspek, yaitu:

1. Penyusunan standar mekanisme pengaduan nasabah

2. Pembentukan lembaga mediasi perbankan

3. Penyusunan standar transparansi informasi produk

4. Peningkatan edukasi untuk nasabah

Program penyusunan mekanisme pengaduan nasabah di bank dan pembentukan lembaga mediasi perbankan bertujuan untuk mengatasi permasalahan antara nasabah dengan bank. Sedangkan program penyusunan standar transparansi informasi produk perbankan ditujukan sebagai sarana awal untuk mencegah timbulnya permasalahan antara nasabah dengan bank.

Terkait mekanisme pengaduan nasabah di bank, Bank Indonesia telah mengeluarkan Peraturan Bank Indonesia Nomor: 7/7/PBI/2005 tentang Penyelesaian Pengaduan Nasabah. Mekanisme pengaduan nasabah diserahkan kepada Unit Pengaduan Internal Bank sehingga bank wajib menetapkan kebijakan dan memiliki prosedur tertulis yang meliputi:

1. Penerimaan Pengaduan

a. Pengaduan dapat dilakukan secara lisan atau tertulis (dilengkapi fotokopi identitas dan dokumen pendukung lainnya) 
b. Penerimaan Pengaduan dilakukan pada setiap Kantor Bank dan tidak terbatas hanya pada Kantor Bank tempat Nasabah membuka rekening dan atau Kantor Bank tempat Nasabah melakukan Transaksi Keuangan.

c. Bank wajib menyampaikan bukti tanda terima Pengaduan kepada Nasabah atau Perwakilan Nasabah yang ditandatangani petugas yang menerima Pengaduan dan memuat: nomor registrasi Pengaduan, tanggal penerimaan Pengaduan, nama Nasabah, nama dan nomor telepon petugas Bank yang menerima Pengaduan, dan deskripsi singkat Pengaduan.

2. Penanganan dan Penyelesaian Pengaduan

a. Bank wajib menyelesaikan Pengaduan paling lambat 20 hari kerja setelah tanggal penerimaan Pengaduan tertulis dan dapat memperpanjang 20 hari kerja.

b. Hasil penyelesaian Pengaduan dapat dibuat secara tertulis atau lisan kepada Nasabah atau Wakil Nasabah sesuai batas waktu yang ditentukan dengan memuat: Nomor registrasi Pengaduan, Permasalahan yang diadukan, dan Hasil penyelesaian Pengaduan yang disertai penjelasan dan alasan yang cukup.

3. Pemantauan Penanganan dan Penyelesaian Pengaduan

a. Bank wajib menyampaikan laporan penanganan dan penyelesaian Pengaduan secara triwulanan kepada Bank Indonesia.

b. Bank Umum yang terlambat menyampaikan laporan penanganan dan penyelesaian pengaduan dikenakan sanksi membayar sebesar Rp1.000.000,00 per hari kerja keterlambatan. Apabila tidak menyampaikan laporan sama sekali maka dikenakan sanksi membayar sebesar Rp. 30.000.000,00.

c. BPR yang terlambat menyampaikan laporan penanganan dan penyelesaian pengaduan dikenakan sanksi membayar sebesar Rp. 100.000,00 per hari kerja keterlambatan. Apabila tidak menyampaikan laporan sama sekali maka dikenakan sanksi membayar sebesar Rp. 250.000,00. 
Sedangkan terkait pembentukan lembaga mediasi perbankan, Bank Indonesia telah mengeluarkan Peraturan Bank Indonesia Nomor: 8/5/PBI/2006 tentang Mediasi Perbankan.Berdasarkan Pasal 1 ayat 5 PBI No: 8/5/PBI/2006, bahwa yang dimaksud dengan pengertian Mediasi adalah proses penyelesaian Sengketa yang melibatkan mediator untuk membantu para pihak yang bersengketa guna mencapai penyelesaian dalam bentuk kesepakatan sukarela terhadap sebagian ataupun seluruh permasalahan yang disengketakan.

Mediasi perbankan merupakan penyelesaian sengketa antara nasabah dan bank yang dibantu oleh mediator. Adapun caranya adalah dengan cara memanggil, mempertemukan hingga memotivasi bank maupun nasbah sehingga mencapai keputusan tanpa memberikan rekomendasi atau putusan.

Penyelesaiannya bersifat win-win solution maksudnya tidak ada pihak yang menang atau kalah. Segala bentuk komunikasi, negosiasi dan pernyataan dibuat dalam proses mediasi berlaku sebagai informasi yang bersifat tertutup maupun rahasia. Para pihak yang tidak mendapat mencapai kesepakatan dapat melakukan upaya penyelesaian lainnya melalui jalur arbitrase maupun litigasi.

Lembaga Mediasi Perbankan dilakukan oleh lembaga Mediasi perbankan independen yang dibentuk asosiasi perbankan dan dalam pelaksanaan tugasnya, berkoordinasi dengan Bank Indonesia. Salah satu unsur utama dalam lembaga mediasi ini adalah adanya seorang atau lebih mediator. Salah satu tujuannya adalah membantu mencarikan jalan keluar (alternative) penyelesaian atas sengketa yang timbul diantara para pihak yang disepakati dan dapat diterima oleh para pihak yang bersengketa.

Persyaratan sengketa yang dapat di mediasi, diantaranya:

a. Diajukan secara tertulis dengan disertai dokumen pendukung yang memadai.

b. Pernah diupayakan penyelesaiannya melalui bank

c. Sengketa yang diajukan tidak sedang dalam proses atau belum pernah diputus oleh lembaga arbitrase atau peradilan, atau belum terdapat kesepakatan.

d. Sengketa yang diajukan belum pernah diproses dalam mediasi perbankan yang difasilitasi BI. 
e. Pengajuan penyelesaian sengketa tidak melebihi 60 hari kerja sejak tanggal surat hasil penyelesaian pengaduan yang disampaikan bank pada nasabah.

f. Nilai tuntutan finansial yang diajukan paling banyak sebesar Rp. 500 juta untuk setiap kasus sengketa.

g. Tidak mengajukan tuntutan finansial yang diakibatkan oleh kerugian immaterial.

Unsur penting yang hasus ada dalam mediasi adalah adanya mediator. Syarat-syarat menjadi seorang mediator adalah sebagai berikut:

a. Memiliki pengetahuan di bidang perbankan, keuangan, dan atau hukum.

b. Tidak mempunyai kepentingan finansial atau kepentingan lain atas penyelesaian sengketa.

c. Tidak memiliki hubungan sedarah atau semenda sampai dengan derajat kedua dengan Nasabah atau Perwakilan Nasabah dan Bank.

Proses beracara Lembaga Mediasi Perbankan adalah sebagai berikut:

a. Pengajuan

Persyaratan pengajuan sebagai berikut:

1) Diajukan secara tertulis dengan disertai dokumen pendukung yang memadai;

2) Pernah diajukan upaya penyelesaiannya oleh Nasabah kepada Bank;

3) Sengketa yang diajukan tidak sedang dalam proses atau belum pernah diputus oleh lembaga arbitrase atau peradilan, atau belum terdapat Kesepakatan yang difasilitasi oleh lembaga Mediasi lainnya;

4) Sengketa yang diajukan merupakan Sengketa keperdataan;

5) Sengketa yang diajukan belum pernah diproses dalam Mediasi perbankan yang difasilitasi oleh Bank Indonesia;

6) Pengajuan penyelesaian Sengketa tidak melebihi 60 hari kerja sejak tanggal surat hasil penyelesaian Pengaduan yang disampaikan Bank kepada Nasabah. 
7) Proses Mediasi dilaksanakan setelah Nasabah atau Perwakilan Nasabah.

8) Bank menandatangani perjanjian Mediasi (agreement to mediate) yang memuat kesepakatan memilih Mediasi dan persetujuan untuk patuh dan tunduk pada aturan Mediasi yang ditetapkan oleh Bank Indonesia.

b. Pemeriksaan

Pelaksanaan proses Mediasi sampai dengan ditandatanganinya Akta Kesepakatan dilakukan dalam jangka waktu paling lama 30 hari kerja sejak Nasabah atau Perwakilan Nasabah dan Bank menandatangani perjanjian Mediasi (agreement to mediate) dan dapat diperpanjang sampai dengan 30 hari kerja berikutnya berdasarkan Kesepakatan Nasabah atau Perwakilan Nasabah dan Bank.

\section{c. Putusan}

Kesepakatan antara Nasabah atau Perwakilan Nasabah dengan Bank yang dihasilkan dari proses Mediasi dituangkan dalam Akta Kesepakatan yang ditandatangani oleh Nasabah atau Perwakilan Nasabah dan Bank.

Bank yang melanggar tidak memenuhi panggilan BI, tidak mengikuti dan mentaati perjanjian Mediasi, tidak melaksanakan hasil penyelesaian Sengketa perbankan dalam Akta Kesepakatan maka dikenakan sanksi administratif berupa teguran tertulis.

Bank Indonesia mencatat pengaduan nasabah kepada industri perbankan meningkat signifikan selama 3 tahun terakhir. Menurut Direktur Departemen dan Perlindungan Konsumen Perbankan Bank Indonesia, Prabowo, mengatakan bahwa pengaduan dari nasabah menunjukan bahwa pelayanan industri perbankan masih ada yang kurang baik. Kebanyakan pengaduan yang masuk berkaitan dengan penghimpunan dana, penyaluran dana, sistem pembayaran, dan alat pembayaran. Berdasarkan data bank sentral, jumlah pengaduan mencapai 679.035 pada tahun 2010. Meningkat menjadi 853.892 pengaduan pada tahun 2011 dan terus meningkat menjadi 884.454 pada tahun 2012. Departemen Investigasi dan Mediasi Perbankan (DIMP) Bank Indonesia mencatat sudah terdapat 361 permohonan 
mediasi terhadap kasus sengketa bank dan nasabah sepanjang JanSept 2013. ${ }^{4}$

Kepala Divisi Mediasi Perbankan Bank Indonesia, Rudy Agus Purnomo, mengatakan bahwa selama 2012 jumlah pengaduan nasabah mencapai 1.032 laporan. Sebanyak 138 memenuhi persyaratan untuk memenuhi syarat dilakukan mediasi dan 113 kasus telah diselesaikan sedangkan 25 lainnya masih berjalan. Terdapat 72 kasus diselesaikan di pra mediasi yakni pada tahap klarifikasi, 41 kasus selesai saat tahap mediasi, dengan rincian 31 sepakat untuk sepakat dan 10 sepakat untuk tidak sepakat. ${ }^{5}$

Dengan demikian peran lembaga mediasi perbankan independen sudah dirasakan sangat perlu untuk segera dapat membantu menyelesaikan sengketa-sengketa perbankan di Indonesia dengan cara sederhana, murah, dan cepat.

\section{Kesimpulan}

Berdasarkan uraian di atas dapat disimpulkan bahwa Pelaksanaan penyelesaian sengketa perbankan melalui lembaga mediasi perbankan dilakukan melalui 2 tahapan yaitu tahap pertama penyelesaian pengaduan nasabah dilakukan di Unit Internal Bank. Apabila Nasabah tidak puas maka bisa menggunakan tahap yang kedua yaitu melalui lembaga mediasi perbankan yang sementara waktu difasilitasi olehBank Indonesia selama Lembaga Mediasi Perbankan Independen belum terbentuk.

\section{DAFTAR PUSTAKA}

Abdul Ghafur Anshori, Peradilan Agama Di Indonesia Pasca UU No.3 Tahun 2006, UII Press, Yogyakarta, 2007.

Ais Chatamarrasjid, Penyelesaian Konflik: Arbitrase dan Pengadilan, Jakarta, 1999.

4 Dinda Wulandari, BI: Pengaduan Nasabah Melonjak dalam 3 Tabun Terakhir, Bisnis.com, Rabu 30 oktober 2013: 17.29 Wib.

5 infobanknews.com, Rabu 20 Maret 2013. 
140 | Adliya, Vol. 8 No. 1, Edisi: Januari-Juni 2014

Christopher W. Moore, Mediasi Lingkungan, Indonesian Center for Environmental Law dan CDR Associate, Jakarta, 1995.

Djuhaendah Hasan, Lembaga Jaminan Kebendaan Bagi Tanab dan Benda Lain Yang Melekat Pada Tanah, Konsep Penerapan Horizontal, Binacipta, Bandung, 1996.

Gary Googpaster, Negosiasi dan Mediasi: Sebuah pedoman Negosiasi dan Penyelesaian Sengketa Melalui Negosiasi, Elips Project, Jakarta, 1993.

Huala Adolf, Hukum Penyelesian Sengketa Internasional, Sinar Grafika, Jakarta, 2004.

Mochtar Kusumaatmadja, Pengantar Ilmu Hukum, Alumni, Bandung, 2000.

nan, Alumni, Bandung, 2006.

M. Yahya Harahaf, Beberapa Tinjauan Mengenai Sistem Peradilan dan Penyelesaian Sengketa, Citra Aditya Bakti, Bandung, 1997.

Ronny Hanitijo Soemitro, Metodologi Penelitian Hukum dan Jurimetri, Ghalia Indonesia, Jakarta, 1994.

Soerjono Soekanto, Pengantar Penelitian Hukum, Penelitian UI-Press, Jakarta, 1986.

Suyud Margono, ADR \& Arbitrase: Proses Pelembagaan dan Aspek Hukum, Ghalia Indonesia, Bogor, 2004.

\section{A. Perundang-undangan \\ UUD 1945}

UU No. 7 Tahun 1992 tentang Perbankan.

UU No. 10 Tahun 1998 tentang Perubahan Atas UU No. 7 Tahun 1992 tentang Perbankan.

UU No.4 Tahun 2004 tentang Kekuasaan Kehakiman

UU No. 8 Tahun 1999 tentang Perlindungan Konsumen.

UU No. 23 Tahun 1999 tentang Bank Indonesia.

UU No. 30 Tahun 1999 tentang Arbitrase dan Alternatif Penyelesaian Sengketa.

UU No. 7 Tahun 1989 tentang Peradilan Agama.

UU No. 3 Tahun 2006 tentang Perubahan Atas UU No. 7 Tahun 1989 tentang Peradilan Agama.

PBI No. 7/7/PBI/2005 tentang Penyelesaian Pengaduan Nasabah. 
PBI No. 8/5/PBI/2006 tentang Mediasi Perbankan.

PBI No. 10/1/PBI/2008 tentang Perubahan Atas PBI Nomor:8//5/PBI/2006 tentang Mediasi perbankan.

Peraturan Otoritas Jasa Keuangan (OJK) No.1/POJK.07/2014 Tahun 2014 tentang Lembaga Alternatif Penyelesaian Sengketa Disektor Jasa Keuangan

\section{B. Internet}

Adi Condro Bawono, Pembentukan Lembaga Mediasi Perbankan Kembali Diamanatkan, Rabu, 09 April 2014.

Dinda Wulandari, BI: Pengaduan Nasabah Melonjak dalam 3 Tabun Terakbir, Bisnis.com, Rabu 30 oktober 2013: 17.29 Wib. infobanknews.com, Rabu 20 Maret 2013. www.hukumonline.com www.bi.go.id 
